\title{
A tetragonal tungsten bronze-type photocatalyst: Ferro-paraelectric phase transition and photocatalysis
}

\author{
Dayong Fan a,c, Ruifeng Chong a,b,c, Fengtao Fan ${ }^{\text {a,b }}$, Xiuli Wang a,b, Can Li ${ }^{\text {a,b }}$, Zhaochi Feng a,* \\ a State Key Laboratory of Catalysis, Dalian Institute of Chemical Physics, Chinese Academy of Sciences, Dalian 116023, Liaoning, China \\ b Dalian National Laboratory for Clean Energy, Dalian Institute of Chemical Physics, Chinese Academy of Sciences, Dalian 116023, Liaoning, China \\ c Graduate University of Chinese Academy of Sciences, Beijing 100049, China
}

\section{A R T I C L E I N F O}

Article history:

Received 27 March 2016

Accepted 1 May 2016

Published 5 August 2016

\section{Keywords:}

Photocatalysis

Ferro-paraelectric phase transition

$\mathrm{Sr}_{0.7} \mathrm{Ba}_{0.3} \mathrm{Nb}_{2} \mathrm{O}_{6}$

Anomalous photovoltaic effect

Temperature-dependent photolumi-

nescence excitation spectrum

\section{A B S T R A C T}

Although ferroelectrics have potential applications in photocatalysis due to their highly efficient charge separation, their mechanism of charge separation is still unknown. A ferroelectric $\mathrm{Sr}_{0.7} \mathrm{Ba}_{0.3} \mathrm{Nb}_{2} \mathrm{O}_{6}$ (SBN-70) semiconductor with a low ferro-paraelectric phase transition $\left(65^{\circ} \mathrm{C}\right)$ was studied. The photocatalytic activity for $\mathrm{H}_{2}$ production by ferroelectric and paraelectric $\mathrm{SBN}-70$ was examined. The spontaneous polarization in the ferroelectric phase strongly affected the photocatalytic performance and parallel ferroelectric domains significantly promoted photogenerated charge separation to result in better photocatalytic $\mathrm{H}_{2}$ production. This knowledge provides an important basis for the fabrication of ferroelectric photocatalysts with improved charge separation ability.

(C) 2016, Dalian Institute of Chemical Physics, Chinese Academy of Sciences. Published by Elsevier B.V. All rights reserved.

\section{Introduction}

In recent years, ferroelectric materials [1,2] were introduced as photocatalysts to improve the charge separation efficiency by their spontaneous electric polarization induced by symmetry breaking. However, the phase-dependent photocatalysis was merely reported. The only example presented was given on $\mathrm{BaTiO}_{3}$ nanoparticles [3]. It was found that the decreased polarization at high temperature was responsible for the decline of photocatalytic activity. $\mathrm{Sr}_{x} \mathrm{Ba}_{1-x} \mathrm{Nb}_{2} \mathrm{O}_{6}$ (SBN) crystals show very strong compositional dependence of the phase transition temperature (Curie temperature, $T_{\mathrm{C}}$ ). With varying Sr content from 0.32 to 0.82 , the $T_{\mathrm{C}}$ can vary from 10 to $270{ }^{\circ} \mathrm{C}$ [4]. Although strontium barium niobate SBN is an extensively studied ferroelectric material for electro-optic and photore- fractive applications [5,6], its application in photocatalysis has not been reported. The ferroelectric relaxor SBN possesses a tetragonal tungsten bronze (TTB) structure with the space group of $\mathrm{P} 4 \mathrm{bm}$ at room temperature. The origin of the ferroelectricity for SBN can be ascribed to the movement of all the metal ions $\left(\mathrm{Sr}^{2+}, \mathrm{Ba}^{2+}\right.$, and $\left.\mathrm{Nb}^{5+}\right)$ out of the nearest oxygen plane in the same direction. This displacement results in spontaneous polarization in the microscopic sized regions, which are called ferroelectric domains [7,8]. After transformation to the paraelectric phase through heating, the polar direction is eliminated [9].

Here, we reported the photocatalytic production of $\mathrm{H}_{2}$ on a $\mathrm{Sr}_{0.7} \mathrm{Ba}_{0.3} \mathrm{Nb}_{2} \mathrm{O}_{6}$ (SBN-70) semiconductor. By comparing the activities of SBN-70 with the low temperature ferroelectric phase and high temperature paraelectric phase, we answer the

\footnotetext{
* Corresponding author. Tel: +86-411-84379303; Fax: +86-411-84694447; E-mail: zcfeng@dicp.ac.cn This work was supported by the National Natural Science Foundation of China $(211373213,21373212)$. DOI: 10.1016/S1872-2067(15)61126-3 | http://www.sciencedirect.com/science/journal/18722067 | Chin. J. Catal., Vol. 37, No. 8, August 2016
} 
key question - whether the separation ability in the ferroelectric phase helps photocatalysis.

\section{Experimental}

\subsection{Sample preparation}

A solid state reaction method was used to prepare $\mathrm{SBN}-70$ polycrystalline samples. High purity $\mathrm{BaCO}_{3}$ (99\%), $\mathrm{SrCO}_{3}$ (99.8\%) and $\mathrm{Nb}_{2} \mathrm{O}_{5}$ (99.9\%) (all from Alfa Aesar) were mixed in the molar ratio $\mathrm{Sr}: \mathrm{Ba}=7: 3$ and ball-milled for $12 \mathrm{~h}$ using ethanol as the medium. After drying, the mixture was calcined at $1300{ }^{\circ} \mathrm{C}$ for $10 \mathrm{~h}$ in an alumina crucible. For photocatalysis, the calcined powders were ground and collected as the photocatalyst. For ferroelectric characterization, the powders were ground again and mixed with polyvinyl alcohol (PVA) as a binder and pressed into disk shaped pellets by uniaxial pressing at $100 \mathrm{MPa}$ for $3 \mathrm{~min}$. The pellets were then sintered at $1350{ }^{\circ} \mathrm{C}$ for $2 \mathrm{~h}$ after pre-sintering at $1250{ }^{\circ} \mathrm{C}$ for $4 \mathrm{~h}$ at the heating rate of $5{ }^{\circ} \mathrm{C} / \mathrm{min}$ to avoid the generation of abnormal grain growth. Ag paste was fired on both sides at $550{ }^{\circ} \mathrm{C}$ for 30 min as electrodes. For the photoelectric measurement, a lateral symmetric structure Ag/SBN/Ag was adopted. The sintered pellets were polished carefully, and then thermal etched in $1300{ }^{\circ} \mathrm{C}$ for $30 \mathrm{~min}$. On the top side of the pellets, two symmetric Ag pastes with stripe shape $(5 \mathrm{~mm} \times 2 \mathrm{~mm})$ were screen printed with an inter-electrode distance of $2 \mathrm{~mm}$ and then fired at the same condition as above.

\subsection{Characterization}

Powder X-ray diffraction (XRD) patterns were recorded on a Rigaku RINT D/Max-2500 powder diffraction system with a Cu $K_{\alpha}$ radiation source. The temperature dependence of the dielectric properties was measured using a computer controlled Agilent 4294A impedance analyzer. The polarization hysteresis loops were recorded using a Radiant Precision LC ferroelectric testing system. An LED lamp $365 \mathrm{~nm}(3.4 \mathrm{eV})$ was used to excite the sample whose energy was in the absorption region of
SBN-70. Two-point dc transport properties were measured both for dark conditions and under illumination by $I-V$ measurements (Keithley model 4200-SCS Semiconductor). The temperature dependent photoluminescence spectra were recorded on an FLS920 fluorescence spectrometer (Edinburgh Instruments). The temperatures of samples were controlled by an Oxford cryostat (model OptistatDN). UV-Vis diffuse reflectance spectra were recorded on a Carry-5000 equipped with an integrating sphere. $\mathrm{BaSO}_{4}$ powders were used as the reference to correct the spectrum.

\subsection{The temperature dependent photocatalytic hydrogen evolution measurement}

The photocatalytic reactions were carried out in a Pyrex reaction cell with quartz cover connected to a closed gas circulation and evacuation system. A sample of $0.2 \mathrm{~g}$ of photocatalyst was dispersed in $200 \mathrm{~mL}$ of aqueous solution containing 10 vol\% methanol as the sacrificial reagent. The suspension was then thoroughly degassed and top-irradiated by a $300 \mathrm{~W}$ Xe lamp (CERMAX PE300BUV). The loading with $0.1 \mathrm{wt} \% \mathrm{Pt}$ co-catalyst was accomplished by an in situ photo-deposition method. The temperature of the reactant solution was controlled by a flow of cooling water $\left(15^{\circ} \mathrm{C}\right)$ or heating in a water bath. After reaction, the solution was cooled to $15^{\circ} \mathrm{C}$ to avoid the sampling difference due to different hydrogen diffusion rates at high temperatures. The amount of hydrogen evolved was determined by an online gas chromatography.

\section{Results and discussion}

\subsection{Phase structural and optical properties}

The XRD pattern of SBN-70 prepared at $1300{ }^{\circ} \mathrm{C}$ for $10 \mathrm{~h}$ is shown in Fig. 1(a). All of the feature peaks match well with the standard TTB SBN structure (JCPDS No. 73-0487), indicating the high purity of the sample. The indirect band gap energy from the Tauc plot (Fig. 1(b)) was obtained from the UV-Vis diffuse reflectance spectrum of the SBN-70 photocatalyst. The
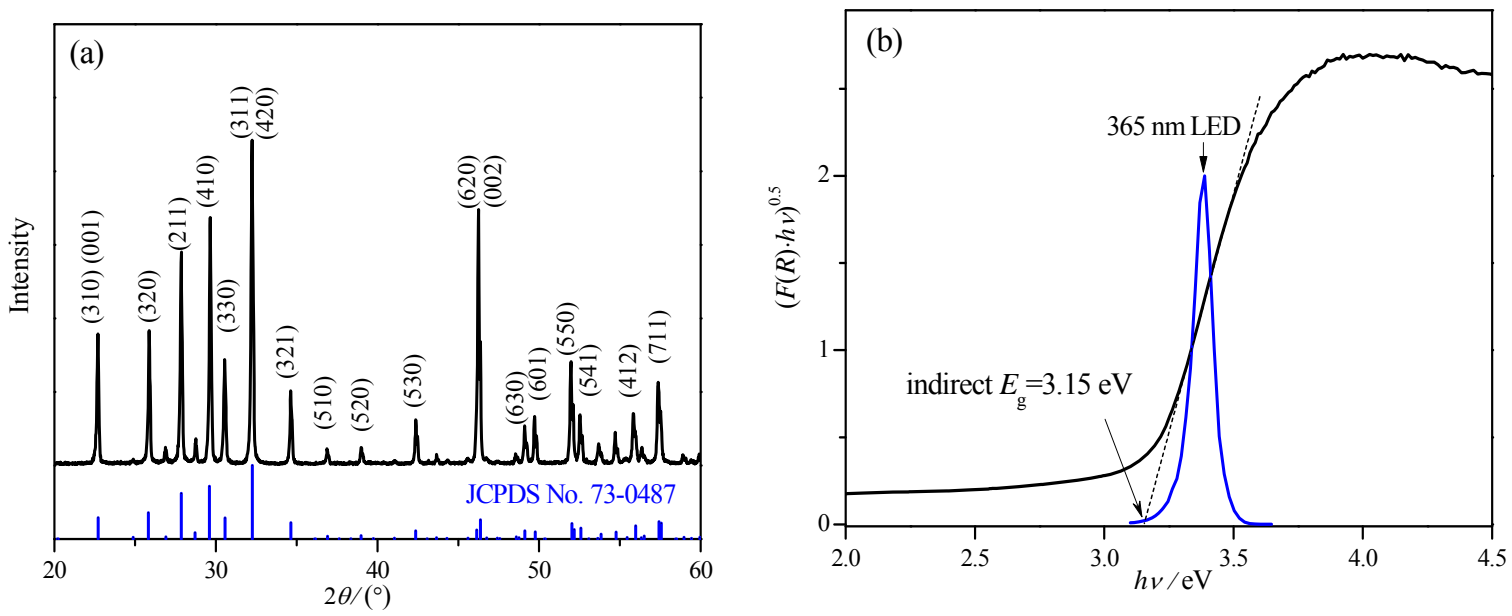

Fig. 1. XRD pattern (a) and Tauc plot from UV-Vis spectrum (b) of the SBN-70 powder sample. 
indirect band gap of SBN-70 was estimated to be $3.15 \mathrm{eV}$. As an oxide with no partly filled $d$-levels, the flat band of SBN-70 can be determined from the relationship [10] $V_{\mathrm{fb}}=2.94-E_{\mathrm{g}}=-0.19$ $\mathrm{V}$ (vs. RHE), which is more negative than the water reduction potential ( $0 \mathrm{~V}$ vs. RHE). The valence band (VB) of SBN-70 can be estimated with the $02 p$ orbitals $(+2.94 \mathrm{~V}$ vs. RHE), which was more positive than the water oxidation potential $(+1.23 \mathrm{~V}$ vs. RHE). Thus, we inferred that as a photocatalyst, SBN-70 has the capability for water splitting from the thermodynamics.

\subsection{Ferroelectric properties}

In Fig. 2(a), SBN-70 shows a typical ferroelectric relaxor behavior. Its dielectric constant exhibited a broad band at different testing frequencies. This strong frequency dependence of the dielectric constant was attributed to intrinsic local polar nanosized regions with different Curie temperatures. Accordingly, the phase transformation temperature of SBN-70 was 65 ${ }^{\circ} \mathrm{C}$. The ferroelectricity of SBN-70 was further examined by the $10 \mathrm{~Hz} P$ - $E$ hysteresis curves at various temperatures with the same maximum applied field of $50 \mathrm{kV} / \mathrm{cm}$ (Fig. 2(b)). Below the temperature of the dielectric peak $\left(65^{\circ} \mathrm{C}\right)$, the sample showed the same polarization $\left(1.4 \mu \mathrm{C} / \mathrm{cm}^{2}\right)$. With increased temperature, the hysteresis loop of SBN-70 became slimmer and the
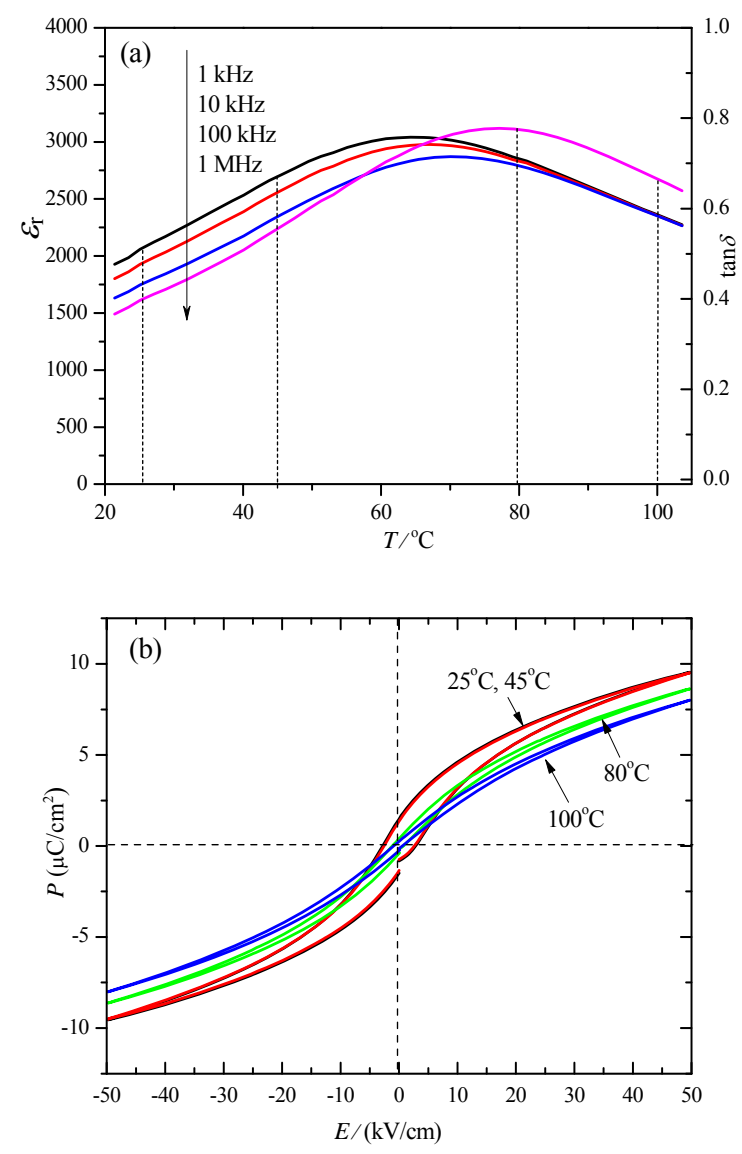

Fig. 2. (a) Temperature and frequency dependence of the dielectric constant of SBN-70; (b) $10 \mathrm{~Hz}$ hysteresis loops measured at 25, 45, 80 and $100{ }^{\circ} \mathrm{C}$ of the SBN-70 pellet with the same maximum applied field of $50 \mathrm{kV} / \mathrm{cm}$. polarization gradually decreased to zero $\left(0.34 \mu \mathrm{C} / \mathrm{cm}^{2}\right.$ at $80{ }^{\circ} \mathrm{C}$, $0.19 \mu \mathrm{C} / \mathrm{cm}^{2}$ at $100{ }^{\circ} \mathrm{C}$ ). These results indicated that the ferro-paraelectric phase transition of SBN-70 occurred at $65{ }^{\circ} \mathrm{C}$. The sample will convert into the paraelectric phase when temperature was above $80^{\circ} \mathrm{C}$.

\subsection{Ferroelectric photovoltaic properties}

To test the anomalous photovoltaic effect (APV) of a ferroelectric semiconductor, a symmetric $\mathrm{Ag} / \mathrm{SBN}-70 / \mathrm{Ag}$ pellet was fabricated to investigate the relationship between polarization and charge separation. Prior to the test, the SBN-70 pellet was poled on the two Ag electrodes with the external electric field for aligning the random domains in one direction. Fig. 3(a)
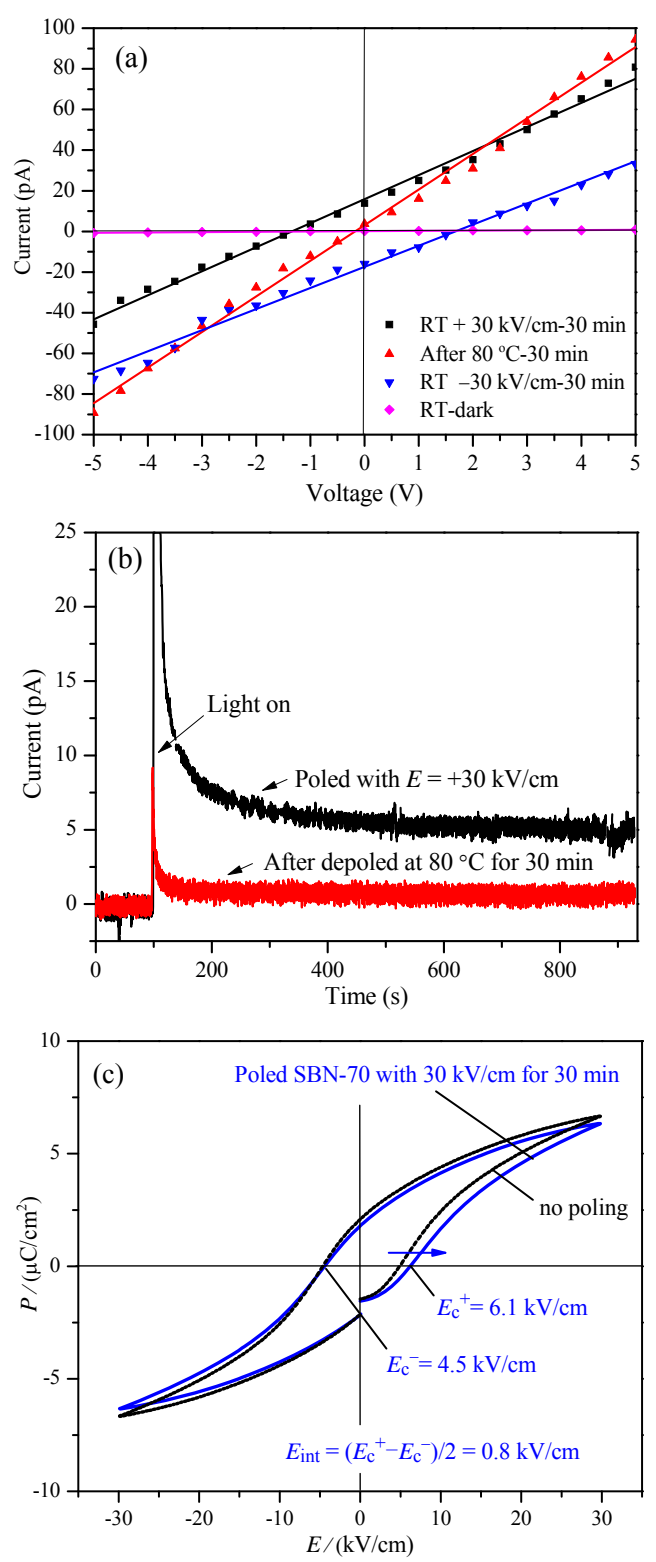

Fig. 3. (a) $I-V$ curves of poled SBN-70 at room temperature (RT) under dark condition or light illumination, poled with $+/-30 \mathrm{kV} / \mathrm{cm}$ or depoled at $80^{\circ} \mathrm{C}$ (red triangle); (b) The time profile of photocurrent of the SBN-70 pellet; (c) The asymmetry $P$ - $E$ loops induced by high electric field poling indicating the existence of an internal electric field $\left(E_{\mathrm{i}}\right)$ [11]. 
shows the $I$ - $V$ curves of the sample after poling with an external electric field $(30 \mathrm{kV} / \mathrm{cm})$ for $30 \mathrm{~min}$. The sample had a considerable open-circuit photovoltage $\left(V_{\text {oc }}\right)$ value of $1.8 \mathrm{~V}$ and a short-circuit photocurrent $\left(I_{\mathrm{sc}}\right)$ of $18 \mathrm{pA}$ when excited with 365 $\mathrm{nm}$ LED irradiation. It was noted that the photovoltaic current flowed in the opposite direction of the poling field. With the reversal of polarization by the opposite poling electrical field, the photovoltaic current direction also reversed. After heating the sample at $80^{\circ} \mathrm{C}$ for $30 \mathrm{~min}$, both of the photo-induced $V_{\text {oc }}$ and $I_{\mathrm{sc}}$ were diminished. The result reflected the strong polarization and phase dependence of the PV effect on the SBN-70 semiconductor.

Fig. 3(b) shows the transient photocurrents of poled SBN-70 before and after the depoling process. The transient photocurrent of the sample poled with $30 \mathrm{kV} / \mathrm{cm}$ gave a sharp increase followed by a relative slow decrease upon light illumination. The photocurrent finally reached a steady state value of $5.1 \mathrm{pA}$. After depoling the sample at $80{ }^{\circ} \mathrm{C}$, the steady state photocurrent had a significantly decrease to $0.7 \mathrm{pA}$. These results suggested that internal polarization fields were formed after poling with the external electrical field, and the photogenerated carriers were separated and transported to the opposite direction with the help of these electrical fields $(\sim 0.8 \mathrm{kV} / \mathrm{cm}$, Fig. $3(\mathrm{c}))$ [11]. With the depoling of the sample at $T>T_{\mathrm{c}}$, the sample will convert into the paraelectric phase while losing the internal driven forces for the charge separation.

\subsection{Temperature dependent photocatalytic $\mathrm{H}_{2}$ production from SBN-70}

It was suggested that the poling process with a high applied electric field will induce the ferroelectric ceramic sample to form a single domain state. The spontaneous polarizations in each domain is aligned with the applied electric field direction. However, our calcined SBN-70 particles have a large size distribution (1-20 $\mu \mathrm{m})$ and contain multiple random oriented domains $[1,2,12]$. Whether these "free" ferroelectric particles with multi-oriented spontaneous polarizations still possess the ability for the separation of photogenerated electrons and

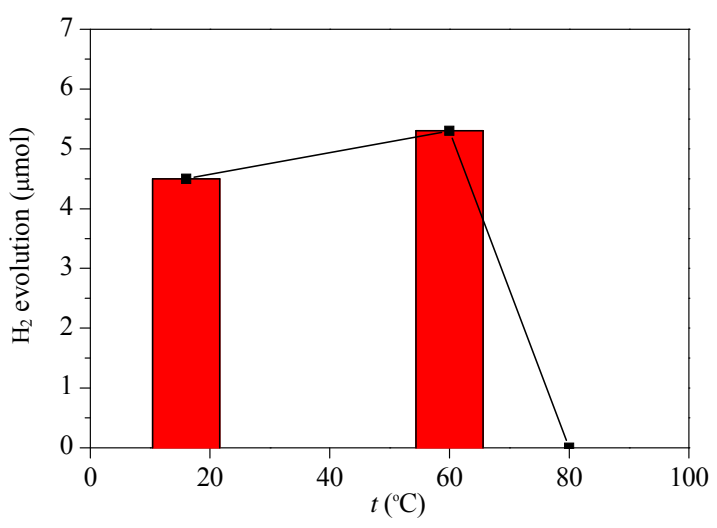

Fig. 4. $\mathrm{H}_{2}$ evolution over $\mathrm{SBN}-70$ photocatalysts from methanol aqueous solution $(10$ vol\%, $200 \mathrm{~mL})$ at 15,60 and $80{ }^{\circ} \mathrm{C} .0 .2 \mathrm{~g} \mathrm{SBN}-70$ with $0.1 \mathrm{wt} \%$ Pt loading as the cocatalyst, reaction time $2 \mathrm{~h}$.

holes, and further promote photocatalytic performances is an essential question. The temperature dependent photocatalytic $\mathrm{H}_{2}$ production of SBN-70 is shown in Fig. 4. All the samples were assembled with hydrogen evolution co-catalysts by in situ $\mathrm{Pt}$ photo-deposition. It was found that after reaction for $2 \mathrm{~h}$, the sample showed $4.5 \mu \mathrm{mol} \mathrm{H}_{2}$ production at $15{ }^{\circ} \mathrm{C}$. With increased reaction temperature to $60{ }^{\circ} \mathrm{C}$, the $\mathrm{H}_{2}$ production showed a slight increase to $5.3 \mu \mathrm{mol}$, which was ascribed to the accelerated surface reaction. It is interesting to find that the activity of the SBN-70 photocatalysts showed a significantly decrease to $0 \mu \mathrm{mol}$ at $80{ }^{\circ} \mathrm{C}$. It should be mentioned that for conventional photocatalysts, it was reported that the photocatalytic reaction is accelerated with increased reaction temperature [13]. The results combined with the temperature dependent photovoltaic test in Fig. 2 and Fig. 3 clearly suggested that the internal polarization fields strongly affected the photocatalytic performance of the sample.

Photoluminescence (PL) is very sensitive to the symmetry of crystal structure [14]. SBN-70 shows PL characterization at low temperatures (Fig. 5(a)). The PL band is located at 750-820 nm with the peak at $767 \mathrm{~nm}$, and the PL excitation (PLE) band is $320-500 \mathrm{~nm}$ with the peak at $395 \mathrm{~nm}$. This PL
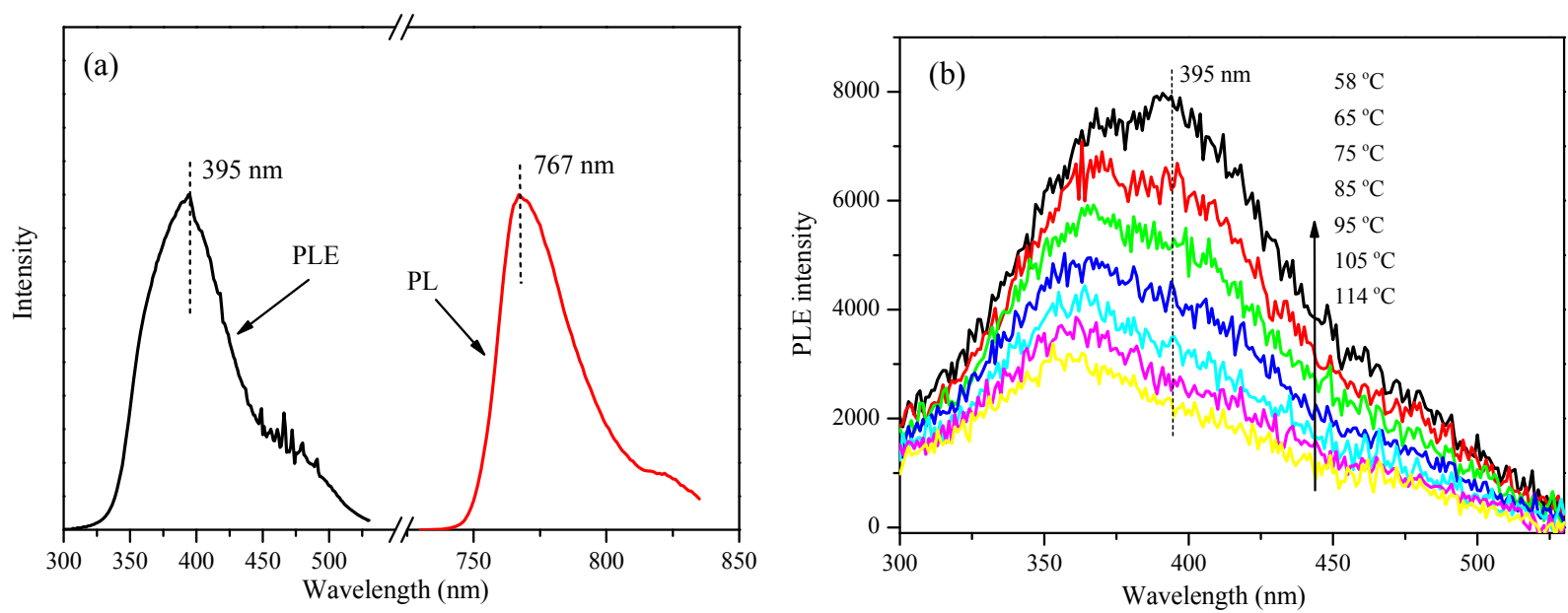

Fig. 5. (a) Normalized PL excitation (PLE) and PL spectra of SBN-70 at $-196{ }^{\circ} \mathrm{C}$; (b) The temperature dependence of PLE spectra of SBN-70 in the process of ferro-paraelectric phase transition, monitored emission at $765 \mathrm{~nm}$. 

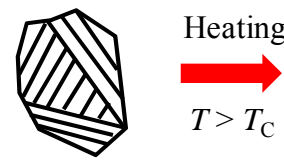

Ferroelectric phase

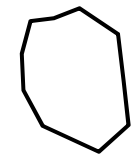

Paraelectric phase

Fig. 6. Schematic showing the temperature evolution of ferroelectric domains in a photocatalyst particle.

band was attributed to the intrinsic radiative transition from excited $\mathrm{NbO}_{6}$ complex [15]. The PL and PLE intensity decreased with measurement temperature increase due to thermal quenching effect (Fig. 5(b)). The PLE peak (395 nm) was totally quenched at $65{ }^{\circ} \mathrm{C}$, which agreed with the phase transition temperature of SBN-70. Thus, it was concluded that the presence of the polar domains below $T_{\mathrm{C}}$ significantly enhanced the PL emission intensity due to the polar direction [16].

The strong temperature dependence of the photocatalytic activity of SBN-70 was associated with the phase transition of SBN-70 from the ferroelectric phase to paraelectric phase (Fig. 6 ). The polar structure of ferroelectric $S B N-70$ provided the driving force for photogenerated electron-hole separation. Although it was argued that multiple domains with different directions can induce a zero net polarization in a bulk ferroelectric particle [17], we still observed that the spontaneous polarization favored charge separation in each separated domain and consequently enhanced the photocatalytic activity.

\section{Conclusions}

The relationship between photocatalysis and ferroelectricity was investigated on the TTB structure $\mathrm{Sr}_{0.7} \mathrm{Ba}_{0.3} \mathrm{Nb}_{2} \mathrm{O}_{6}$ (SBN-70). The ferro-paraelectric phase transition temperature (Curie point, $T_{\mathrm{C}}$ ) of SBN-70 was revealed by temperature dependent dielectric and polarization hysteresis measurements as $65{ }^{\circ} \mathrm{C}$. In the temperature dependent photocatalytic experi-

ments, the photocatalytic reaction occurred when SBN-70 was in the ferroelectric phase but not in the paraelectric phase. A strong polarization and phase dependence of the photovoltaic effect were verified on the SBN-70 pellet. The totally quenching of the PLE peak above $T_{\mathrm{C}}$ indicated the lost of its polar structure although SBN-70 was in an unpoled state. Our results suggested that the internal electric field induced by spontaneous polarization in the ferroelectric phase strongly enhanced the photocatalytic performance of the sample, which benefited from the strong photogenerated charge separation in each polar domain structure.

\section{References}

[1] C. Y. Chao, Z. H. Ren, Y. H. Zhu, Z. Xiao, Z. Y. Liu, G. Xu, J. Q. Mai, X. Li, G. Shen, G. R. Han, Angew. Chem. Int. Ed., 2012, 51, 9283-9287.

[2] C. Zhen, J. C. Yu, G. Liu, H. M. Cheng, Chem. Commun., 2014, 50, 10416-10419.

[3] R. Su, Y. J. Shen, L. L. Li, D. W. Zhang, G. Yang, C. B. Gao, Y. D. Yang, Small, 2015, 11, 202-207.

[4] C. David, T. Granzow, A. Tunyagi, M. Wöhlecke, Tb. Woike, K. Betzler, M. Ulex, M. Imlau, R. Pankrath, Physica Status Solidi (A), 2004, 201, R49-R52.

[5] T. Volk, L. Ivleva, P. Lykov, N. Polozkov, V. Salobutin, R. Pankrath, M. Wöhlecke, Opt. Mater., 2001, 18, 179-182.

[6] P. Tayebati, D. Trivedi, M. Tabat, Appl. Phys. Lett., 1996, 69, 1023-1025.

[7] H. C. Chen, Y. H. Xu, J. Cryst. Growth, 1989, 96, 357-362.

[8] P. S. Zelenovskiy, V. A. Shikhova, A. V. Ievlev, M. M. Neradovskiy, V. Ya. Shur, Ferroelectrics, 2012, 439, 33-39.

[9] A. M. Glass, J. Appl. Phys., 1969, 40, 4699-4713.

[10] D. E. Scaife, Sol. Energy, 1980, 25, 41-54.

[11] L. Jin, F. Li, S. J. Zhang, J. Am. Ceram. Soc., 2014, 97, 1-27.

[12] V. V. Shvartsman, W. Kleemann, T. Łukasiewicz, J. Dec, Phys. Rev. B, 2008, 77, 054105/1-054105/7.

[13] M. Yi, [PhD Dissertation], Dalian Institute of Chemical Physics, Chinese Academy of Sciences, Dalian, 2012.

[14] M. O. Ramirez, D. Jaque, M. Montes, J. Garcia. Solé, L. E. Bausá, L.

\section{Graphical Abstract}

Chin. J. Catal., 2016, 37: 1257-1262 doi: 10.1016/S1872-2067(15)61126-3

A tetragonal tungsten bronze-type photocatalyst: Ferro-paraelectric phase transition and photocatalysis

Dayong Fan, Ruifeng Chong, Fengtao Fan, Xiuli Wang, Can Li, Zhaochi Feng* Dalian Institute of Chemical Physics, Chinese Academy of Sciences; Graduate University of Chinese Academy of Sciences

The relationship between ferroelectricity and photocatalytic activity was investigated on $\mathrm{Sr}_{0.7} \mathrm{Ba}_{0.3} \mathrm{Nb}_{2} \mathrm{O}_{6}$ (SBN-70). The photocatalytic reaction occurred in the ferroelectric phase but not the paraelectric phase. The ferroelectric polar domains facilitated photogenerated electron-hole separation.

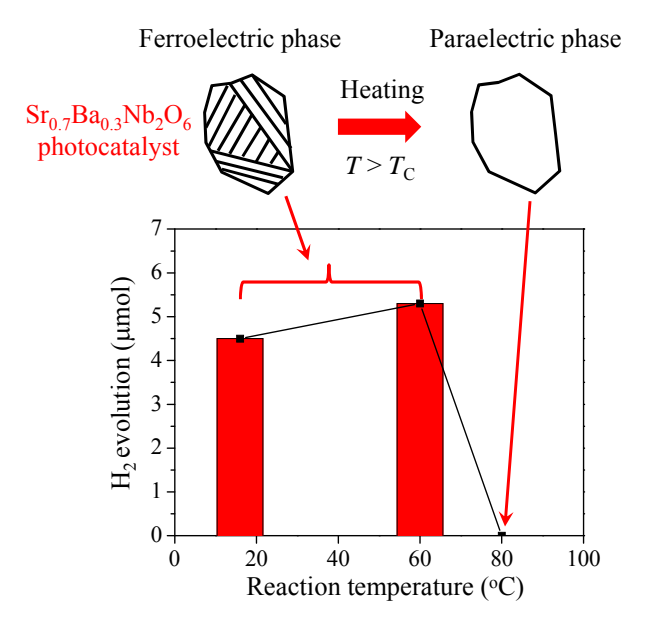


Ivleva, Appl. Phys. Lett., 2004, 84, 2787-2789.

[15] A. Kh. Zeinally, N. N. Lebedeva, A. R. Mordukhayev, M. A. Osman, Ferroelectrics, 1982, 45, 83-88.
[16] X. L. Tian, Z. Wu, Y. M. Jia, J. R. Chen, R. K. Zheng, Y. H. Zhang, H. S. Luo, Appl. Phys. Lett., 2013, 102, 042907/1-042907/3.

[17] J. L. Giocondi, G. S. Rohrer, Top. Catal., 2008, 49, 18-23.

\title{
一种乌青铜结构光催化剂: 铁电-顺电相变与光催化性质
}

\author{
范大勇, 种瑞峰 ${ }^{\mathrm{a}, \mathrm{b}, \mathrm{c}}$, 范峰滔 ${ }^{\mathrm{a}, \mathrm{b}}$, 王秀丽 ${ }^{\mathrm{a}, \mathrm{b}}$, 李 灿 ${ }^{\mathrm{a}, \mathrm{b}}$, 冯兆池 ${ }^{\mathrm{a},}{ }^{*}$ \\ ${ }^{\mathrm{a}}$ 中国科学院大连化学物理研究所催化基础国家重点实验室, 辽宁大连 116023 \\ $\mathrm{b}$ 中国科学院大连化学物理研究所洁净能源国家实验室(筹), 辽宁大连 116023 \\ ${ }^{\mathrm{c}}$ 中国科学院大学, 北京 100049
}

摘要: 近年来, 铁电材料作为一种潜在的高活性光催化剂材料越来越多地受到研究者关注. 由于晶体结构的对称性破缺导 致铁电晶体中出现自发极化, 在这种极化内建电场的影响下, 光生电子-空穴将发生空间分离, 从而有效抑制载流子复合, 进一步提高光催化体系的总量子效率. 文献报道了很多性能优异的铁电光伏器件, 在这样的思路下, 越来越多的材料被直 接作为光催化材料来研究, 但有关顺电-铁电差异的报道很少, 铁电性与光催化性能关联的直接证据尚有欠缺.

研究表明, $\mathrm{Sr}_{x} \mathrm{Ba}_{1-x} \mathrm{Nb}_{2} \mathrm{O}_{6}(\mathrm{SBN})$ 材料的居里温度 $\left(T_{\mathrm{C}}\right)$ 对组分调变有很强的依赖性, 当 $\mathrm{Sr}^{2+}$ 含量发生改变时 $(x=$ 0.32-0.82), 其居里温度可在 $10-270{ }^{\circ} \mathrm{C}$ 范围内变化. 因此, 合成一个居里温度接近室温的 $\mathrm{SBN}$ 材料, 研究其在顺/铁电相下 自发极化行为、光生电荷分离行为、光催化行为及结构演变, 就可能得到一个关于铁电性与光催化性能关系的直接证据, 并 有助于理解二者的关联性. 本文以较低温度 $\left(65^{\circ} \mathrm{C}\right)$ 下发生铁-顺电相变的 $\mathrm{Sr}_{0.7} \mathrm{Ba}_{0.3} \mathrm{Nb}_{2} \mathrm{O}_{6}(\mathrm{SBN}-70)$ 材料为模型体系, 使用 $\mathrm{X}$ 射线衍射、紫外可见光谱及不同温度下的铁电及介电测试、光电测试、光催化产氢和荧光激发谱等表征技术, 研究了 $\mathrm{SBN}-70$ 光电/光催化性能差异与相结构的相关性.

首先使用高温固相合成法制备了纯相的四方钨青铜型 SBN-70 材料, 根据紫外可见漫反射光谱表征结果, 推测 SBN-70 材料在热力学上可发生光催化水分解反应. 对 SBN-70 进行的铁电及介电测试表明 SBN-70 属于典型的弛豫型铁电材料: 介电峰温度宽化显著, 且介电峰位置随不同测试频率发生变化. 在 $f=1 \mathrm{kHz}$ 测试下, 其名义居里温度约为 $65^{\circ} \mathrm{C}$. 使用高 温下两步烧结法制备了致密的 $\mathrm{Ag} / \mathrm{SBN}-70 / \mathrm{Ag}$ 陶瓷样品. 受到高强度电场 $(E=30 \mathrm{kV} / \mathrm{cm})$ 极化的 $\mathrm{Ag} / \mathrm{SBN}-70 / \mathrm{Ag}$ 样品在紫 外光照射下出现了显著光伏效应, 铁电回线测试表明极化后的 SBN-70 材料中存在强度约为 $0.8 \mathrm{kV} / \mathrm{cm}$ 由剩余极化导致的 内建电场, 当经过极化的 SBN-70 经过 $80^{\circ} \mathrm{C}$ 退火后, 光伏效应消失. 结果表明, SBN-70 极化后在内建极化场的作用下, 在 低温铁电相表现了显著的光生电荷分离能力, 在进入高温顺电相后, 这种分离能力随着自发极化的消失而消失. 同时我们 发现担载 Pt 的 SBN-70 粉末样品作为光催化剂在不同温度下存在很大的光催化产氢活性差异: 反应在 $15^{\circ} \mathrm{C}$ 时, 产氢量为 $4.5 \mu \mathrm{mol}$, 随着反应温度升高, 其产氢量升高, 在 $60^{\circ} \mathrm{C}$ 时为 $5.3 \mu \mathrm{mol}$, 继续升高温度至 $80^{\circ} \mathrm{C}$ 时, 发生了反常的活性变化, 即 产氢活性完全消失. 这种反常的活性-温度关系可能与 SBN-70 的铁-顺电相变有关: 进入高温顺电相 $\left(80^{\circ} \mathrm{C}\right)$ 后, 晶体结构 回到 $4 / \mathrm{mmm}$ 点群, 铁电畴结构不再存在, 从而丧失了作为电荷分离驱动力的自发极化. 不同温度下荧光激发谱结果也暗 示了 SBN-70 在高于 $65^{\circ} \mathrm{C}$ 附近极化结构的消失. 本文结果表明, 铁电相中存在的铁电极化结构确实有利于光生电荷分离, 进而提高了光催化反应活性.

关键词: 光催化; 铁-顺电相变; 锶钡铌氧; 反常光电效应; 变温荧光激发谱

收稿日期: 2016-03-27. 接受日期: 2016-05-01. 出版日期: 2016-08-05.

*通讯联系人. 电话: (0411)84379303; 传真: (0411)84694447; 电子信箱: zcfeng@dicp.ac.cn

基金来源：国家自然科学基金 (211373213; 21373212).

本文的英文电子版由Elsevier出版社在ScienceDirect上出版(http://www.sciencedirect.com/science/journal/18722067). 